\title{
Teoria e epistemologia do conhecimento arqueológico
}

A Arqueologia, desde o início, esteve na dependência de uma questão epistemológica de fundo: como se pode conhecer algo por meio de meros vestígios materiais? Nos séculos do Antiquariado, desde o Renascimento, antes mesmo da moderna Arqueologia, as estátuas antigas só revelavam os seus segredos por meio de análises comparativas e estilísticas. Não havia conhecimento imediato, nem a mera percepção das pessoas bastava para que se pudessem formular interpretações sobre os objetos artísticos dos antigos. A partir do século XVIII, foi a Filologia, com seus pressupostos filogenéticos e genealógicos a fornecer os parâmetros para entender um universo material crescente e cada vez mais diversificado como uma linguagem a ser decifrada. Em certo sentido, essa abordagem fundada na linguística está na disciplina até hoje, ainda que sob alguns influxos novos, derivados de Saussure ou de Chomsky, temperados pela hermenêutica, essa também baseada no estudo taxonômico.

As décadas recentes testemunharam dois movimentos paralelos, com consequências para a epistemologia da disciplina: a interdisciplinaridade, por um lado, e a abertura para o engajamento com os leigos, com os usuários da materialidade. No primeiro caso, a interação com antropólogos, geógrafos, historiadores, filósofos, cientistas da religião, turismólogos ou museólogos, entre muitos outros, resultou em transformações salutares pelo desafio de observar como a cultura material aparece de forma tão diversa em campos distintos, ainda que sempre mediados pelo estudo especializado. Em seguida, o reconhecimento da necessária ligação entre conhecimento científico e as pessoas comuns fez com que a disciplina tomasse as percepções dos diversos e contraditórios grupos e agentes sociais como produtores, eles mesmos, de conhecimento, na medida em que pudessem fornecer contrapontos à análise especializada do estudioso. Em ambos os casos, não se trata de abandonar, de modo algum, o conhecimento específico, detalhado, erudito, resultado do trabalho árduo em campo, no laboratório e no gabinete, mas de enriquecê-lo pelo contato e interação com outros estudiosos e com os leigos.

A teoria arqueológica, neste sentido, não pode deixar de abranger campos de relevância política, social e pública, ao tratar de tudo que diga respeito a como conhecer pela materialidade a sociedade no presente e no passado. Neste sentido, não se pode desvencilhar a Arqueologia Pública da teoria, pois sem reflexão epistemológica corre-se o risco de um mero engajamento político fácil, mas enganoso, que pode descambar para as posições políticas e acadêmicas mais reacionárias: se basta ao estudioso haurir o que as pessoas acham sobre o mundo material, sem mediação das perspectivas de interpretação, corre-se o risco de disparates que não servem senão a muito poucos. Se couber ao estudioso apenas 
coletar a percepção das pessoas sobre uma suposta ausência de população indígena, no passado, em determinada área, estaremos perpetuando a narrativa da terra nullius que justificou o colonialismo e a expropriação. A teoria, portanto, está na raiz de uma prática crítica a serviço da sociedade, em sua diversidade e contradições, sem restringir-se à legitimação dos discursos advindos do senso comum.

Neste número da revista, apresentam-se diversos estudos a partir dessas premissas. Por um lado, há evidente reflexão transdisciplinar, em particular, pela interface com os estudos do Turismo, do Patrimônio, da Religiosidade, da História, da Sociologia, da Informação, da Epigrafia e da Filosofia. A Arqueologia Pública mostra, assim, que muito se aprende com essa explícita interlocução disciplinar. Em seguida, a reflexão surge nos estudos de caso em que as pessoas comuns estão envolvidas, tanto pelo turismo, como pelo consumo do conhecimento arqueológico, como nos documentários. A entrevista com o professor Pedro Sanches, na mesma linha, retoma a ligação umbilical entre Arqueologia, público e epistemologia, algo que está também na resenha do livro recente de Rosemary Joyce e Susan Gillespie. Passados vinte anos, as palavras de Peter Ucko parecem terem sido premonitórias:

If 'theory' is to be a self-consciously aware but welcoming approach to a diversity of approaches to the past, we may be about to take part in an archaeological development which will reveal how archaeological investigation and interpretation can add a new dimension to the world's understanding of itself (Ucko 1995: 24).

Se 'teoria' for uma abordagem auto-consciente e aberta para a diversidade de perspectivas sobre o passado, podemos estar a ponto de participar de um desenvolvimento na Arqueologia que revelará como a pesquisa e a interpretação arqueológicas podem acrescentar novas dimensões para a compreensão do mundo de si mesmo.

Pedro Paulo A. Funari

Referência

Ucko, P. Introduction: archaeological interpretation in a world context. Theory in Archaeology, A world perspective. London, Routledge, 1995, 1-28. 